\title{
RESEARCH OF THE ENTERPRISE PROFITABILITY STRATEGY
}

\author{
Gennady Shvachych ${ }^{1}$ \\ National Metallurgical Academy of Ukraine, Ukraine \\ Elena Kholod ${ }^{2}$ \\ Alfred Nobel University, Ukraine
}

\begin{abstract}
The article focuses on such indicators as profit and profitability, reflecting the economic efficiency of an enterprise, its financial condition, and the problems of its economic development. The subject of the research is to analyse the profitability of an enterprise and validate the strategy of the enterprise's efficiency increasing. The methodology of the research is based on an analysis of the enterprise efficiency characteristics in general, the profitability of different areas of production. For this purpose, in the economic analysis, in particular, there were used profitability indicators. In this case, profitability is the most generalized, qualitative indicator of the economic efficiency of an entity's activity, which allows comparing the amount of profit with the value of the means, by which it was obtained. The purpose of the research is to analyse the production activity of OJSC "NmTZ" and to develop proposals for improving its production efficiency; study ways of production development; research factors that delay the growth process of pipe products production; identify the profitability growth factors of the enterprise that allow increasing competitiveness indicators in the pipe market. Practical application. The enterprise's priority directions of activity aimed at improving the technique and technology on the basis of modern scientific developments in order to reduce energy and material consumption, as well as to improve the quality of pipe products are shown. The key ways of increasing profit and profitability are indicated. Factors of the income increase, which allow the enterprise to carry out its activities more successfully, are revealed.
\end{abstract}

Key words: profit, profitability, enterprise, economic efficiency, market, competitiveness.

JEL Classification: L11, L16, O14, P11

\section{Introduction}

In an economic analysis, the results of an enterprise can be estimated by such indicators as output, sales, profit, etc. However, when it comes to assessing the effectiveness of an enterprise, it becomes obvious that the listed characteristics are not enough because those are the absolute indicators. In this regard, in order to characterize the efficiency of the enterprise in general, the profitability of different areas of production in the economic analysis, there are used, in particular, the indicators of profitability. Profitability in the broad sense of the word means efficiency and returns (Balabanov, 2007). Profitability is the most generalized, qualitative indicator of the economic efficiency of an entity's activity; it allows you to compare the amount of profit with the value of the means, by which it was obtained. Therefore, profitability can be interpreted as a measure of returns, reinunerativeness, and business efficiency.
Relative indicators that allow one to evaluate the efficiency of an enterprise in general, as well as directions of its activities (production, commercial, investment, etc.), the profitability of production of certain types of products and definite services rendering measure profitability.

It should be noted that the indicators of profitability are important elements that reveal the factor environment of profit generation, so they are mandatory in conducting a comparative analysis and assessment of the financial condition of the enterprise. In addition, profitability is important for decision-making in investment, planning, budgeting, coordination, evaluation, and control of the enterprise activity.

The purpose of the article is:

- analysis of production activity of NmTZ OJSC and proposals development for improving its production efficiency;

\footnotetext{
Corresponding author:

${ }^{1}$ Department of Applied Mathematics and Computer Science, National Metallurgical Academy of Ukraine.

E-mail: sgg1@ukr.net

${ }^{2}$ Department of Economic Cybernetics and Mathematical Methods in Economics, Alfred Nobel University.

E-mail: sgg1@ukr.net
} 
- research of ways of production development;

- research of factors that delay the production growth process of pipe products;

- identification of profitability growth factors of an enterprise that allow increasing the competitiveness indicators in the pipe market;

- definition of directions of optimal production process development.

\section{Analysis of recent research and publications}

One of the main results of an enterprise is profit, which is an absolute indicator of its efficiency. A significant contribution to solving the problem of improving the efficiency of enterprises belongs to such economists as V.H. Andriichuk, M.Ya. Demianenko, V.N. Kosinsky, P.M. Makarenko, L.L. Melnyk, N.M. Bohatska, P.T. Sabluk et al. (Andriichuk, 2014; Melnyk, 2013; Sabluk, 2008; Parshyna, 2013). Thoroughly this problem in the classical form is reflected in the researches of E.I. Krylov, V.M. Vlasova, I.V. Zhuravkova, T.U. Turmanidze, I.A. Blank et al. (Krylov \& Vlasova, \& Zhuravkova, 2006; Tumanydze, 2013, Blank, 2007).

Note that some Western economists define profits as a category of well-being. So, J. Hicks stated that the goal of determining profit in practice is to give people a sense of the amount they can spend on consumption without becoming poorer. The essence of this provision is that profit should be considered as the maximum amount that a person can spend, provided that his/her welfare will not have been decreased by the end of a certain control period. At the current stage of economic development, most economists also interpret the profit from the economic activity of an enterprise as the excess of income over costs. In particular, S.F. Pokropivnyi (Pokropivnyi, 2001) and N.M. Bondar (Bondar, 2014) consider the profit as a part of the proceeds remaining after the reimbursement of all costs for the production and commercial activities of an enterprise. O.O. Hetman and V.M. Shapoval prove that "profit is the difference between the sale price and the cost price of products (goods, works, services), between the amount of proceeds received and the amount of production and sales costs" (Hetman \& Shapoval, 2010).

The researches of local and foreign scientists attest that the absolute profit size does not allow obtaining a clear idea of the level, or changing in the efficiency of production. Thus, the total amount of profit may increase, when the production efficiency will remain unchanged or even decrease. This situation can take place with the profit growth due to quantitative factors of production. For example, with the equipment and staff expand.

At the same time, we note that the profitability of production (or reinunerativeness) is derivative from the profit (Prokopenko \& Hanin, 2008). In this case, the meaning of profitability in the economic literature is presented in several interpretations. This fact indicates that the profitability of the production relates to the economic category, which is different in its complexity. For instance, in general, it can be noted that the profitability of production is a relative indicator of the economic efficiency of an enterprise. In addition, such an indicator comprehensively represents the use of monetary, labour and production resources. On the other hand, the profitability of production can be interpreted as the ratio of income and the capital invested in creating such income. Consequently, the profitability of a production based on a comparison of the return on investment with the capital invested allows determining the level of profitability of an enterprise and comparing it with the alternative use of capital, received by the enterprise on equal risk terms.

It should be noted that, despite the significant source of research on the theory of an enterprise increasing efficiency, the problem of profit and profitability increasing has not been studied sufficiently. This is especially true in the iron and steel industry, where there is a drop in production.

\section{Research on the production efficiency increasing problem}

Profit, as a source of industrial and social development, is one of the major factors in self-financing of an enterprise. Moreover, the possibilities of an enterprise are mainly determined by the extent, to which its income exceeds costs. Therefore, it is not only profit that plays an important role in the enterprise's activity but also the losses. Those can usually show miscalculations and even errors in the production organization, as well as in sales. The noted points allow asserting that the profit is the result of the activity of an enterprise that indicates its absolute efficiency. Figure 1 shows the main factors of increasing the profit of an enterprise.

Indicators of production profitability are the most important factors for the current planning of an enterprise. They are also taken into account in determining the financial capacity of an enterprise. It is clear that the profitability indicators of an enterprise can be considered as generalizing criteria of economic production efficiency. In general, such indicators reflect the efficiency of usage of money and labour resources. In this case, the enterprise is considered to be profitable if it is remunerative. The study of production profitability indicators can reveal the profit increase factors, as well as indicate the ways of further development of an enterprise. Also, the profitability indicators may show the assessment of the enterprise management effectiveness, as it is obvious that the high-profit level and a significant return of the enterprise directly depend on the effectiveness of management decisions. From 


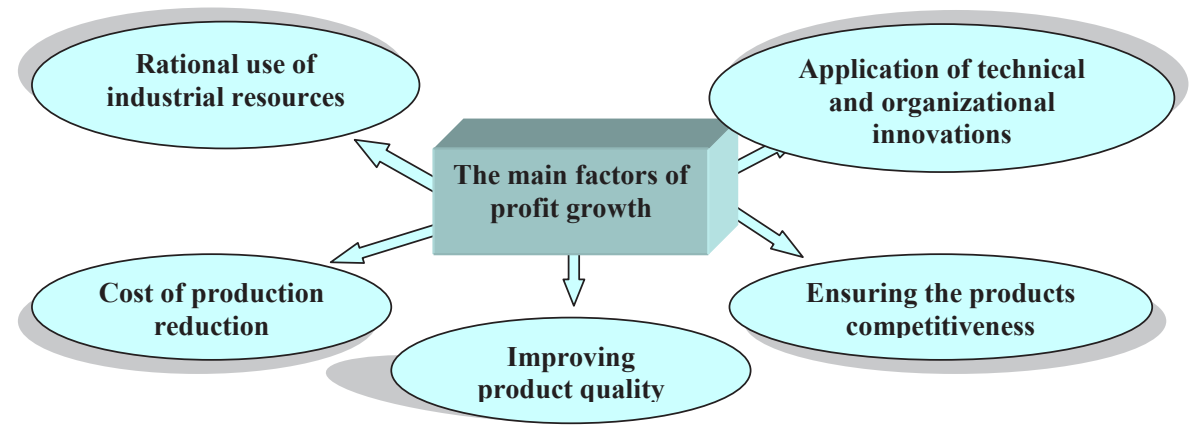

Fig. 1. The main factors of increasing the profit of an enterprise

these positions, the production profitability can be interpreted as one of the most important factors in the quality of the enterprise management.

An enterprise must constantly identify ways to increase profitability for ensuring highest indicators of its activity. The main factors in increasing the production profitability can be defined by the following: the higher the income and the less the value of fixed assets and working capital for its achievement, the higher the production profitability. At the same time, the economic efficiency of an enterprise operation increases significantly.

As a rule, when performing an analysis of ways to increase the production profitability, the influence of external and internal factors is distinguished. External factors in increasing the production profitability can be referred to the sales market expansion of the products at the expense of lower prices for goods produced. Internal factors are considered to be more significant than external ones. These include the following: reducing production cost, increasing production volumes, increasing the return on fixed assets, and so on (Fig. 2).

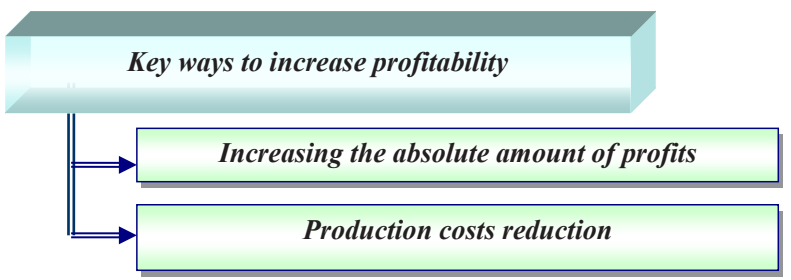

Fig. 2. The key ways to increase profitability

A wide range of indicators may characterize the production profitability. Those show the ways to increase the efficiency of production. On the other hand, profitability indicators are to determine the effectiveness of the funds invested in production. The more so, the assessments analysis of the financial and economic enterprise activity is based on these indicators. The most important ones may include the following. In particular, these are: assets profitability, investment capital profitability, products profitability, ROI of personnel, sales profitability, the coefficient of basic profitability of assets, profitability of net assets, etc.

The direct analysis of assessments of the NmTZ OJSC efficiency was conducted on the basis of determining the following indicators of profitability.

Production profitability:

$\mathrm{PP}=\mathrm{Pr} / \mathrm{PC} \times 100 \%$,

where $\mathrm{PP}$ - production profitability; $\mathrm{PC}$ - production costs; $\mathrm{Pr}$ - profit obtained from the production volume. The share of profits accounted for by $1 \mathrm{UAH}$ spent on production assets characterize such an indicator.

Products profitability:

$\mathrm{PR}=\operatorname{Pr} / \mathrm{C} \times 100 \%$,

where PR - production profitability; $\mathrm{Pr}$ - profit; C cost. It shows the profit amount for $1 \mathrm{UAH}$ of self-cost.

Sales profitability:

$\mathrm{SP}=\operatorname{Pr} / \mathrm{S} \times 100 \%$,

where SP - sales profitability; Pr - profit; S - sales or revenue. The sales profitability is responsible for the profits amount, which accounted for $1 \mathrm{UAH}$ of revenue. Sometimes such an assessment is called general profitability.

\section{Analysis of profit, financial condition and production profitability}

OJSC "NmTZ" is focused on the production of electric welded pipes of various purposes. The priority direction of the plant's activity is the production of pipes of such a diameter as large, medium, and small. Modern technologies and equipment in production, as well as quality control and product testing systems, ensure the production of pipes of the following grades of steel: carbon, low-alloy, and stainless steel. The pipes are produced according to the local and international standards.

The analysis of the financial condition of the enterprise was based on the report that describes the corresponding Balance of the enterprise. Table 1 shows the main indicators of such a Balance.

Table 1 analysis shows the following. The enterprise received a profit of 1419197 thousand UAH from 
Table 1

The main indicators of financial activity of the enterprise

\begin{tabular}{|l|c|c|c|}
\hline \multicolumn{1}{|c|}{ Item } & $\begin{array}{c}\text { Line } \\
\text { code }\end{array}$ & $\begin{array}{c}\text { For the } \\
\text { reporting } \\
\text { period }\end{array}$ & $\begin{array}{c}\text { For the same } \\
\text { period of the } \\
\text { previous year }\end{array}$ \\
\hline $\begin{array}{l}\text { Net income from sales } \\
\text { of goods (goods, works, } \\
\text { services) }\end{array}$ & 2000 & 1498197 & 1842500 \\
\hline $\begin{array}{l}\text { Self-cost of the products } \\
\text { sold (goods, works, } \\
\text { services) }\end{array}$ & 2050 & $(1271830)$ & $(1516403)$ \\
\hline $\begin{array}{l}\text { Gross: } \\
\text { profit }\end{array}$ & 2090 & 226367 & 326097 \\
\hline
\end{tabular}

its activity for the reporting period. This profit amount shows that in comparison with the last year's corresponding indicator, it decreased by $18.7 \%$. It is 423 303 thousand UAH in absolute values. Closer analyses of the enterprise main indicators show the following. The self-cost of production, realized by the enterprise, increased by $8.4 \%$. Thus, at the enterprise, there was a growth in the production self-cost over the income. This situation has led to a $9.8 \%$ decrease in gross profit in general.

A detailed analysis of the situation at the enterprise showed the following. The slowdown in the enterprise performance occurred due to the deteriorating situation in the production and sale of the produced goods, that is, the main activity of the enterprise was in the crisis phase. This explains the costs increase over other activities of the enterprise.

The next step was to analyse the enterprise profitability. Table 2 represents the main profitability indicators. Those show a decrease in the efficiency assessment of the enterprise for all major parameters compared with the last year.

Table 2

Basic indicators of the enterprise profitability

\begin{tabular}{|l|c|c|}
\hline \multicolumn{1}{|c|}{ Profitability } & $\begin{array}{c}\text { For the reporting } \\
\text { period }\end{array}$ & $\begin{array}{c}\text { For the same } \\
\text { period of the } \\
\text { previous year }\end{array}$ \\
\hline Production & 0,166 & 0,143 \\
\hline Products & 0,215 & 0,178 \\
\hline Sales & 0,166 & 0,143 \\
\hline
\end{tabular}

In addition, there were determined other profitability indicators of the enterprise.

Profitability decreased by $16 \%$. Such an assessment showed that $1 \mathrm{UAH}$ of assets accounted for $0.12 \mathrm{UAH}$ of net profit. In the past reporting period, it was $0.28 \mathrm{UAH}$.

The profitability of the net worth decreased by almost 2.1 times. In the previous reporting period, $1 \mathrm{UAH}$ of the net worth accounted for 0.51 UAH, while at the reporting period it was $0.24 \mathrm{UAH}$.

\section{The strategy of increasing the production profitability}

Analysis of the strategy of increasing the production efficiency is based on the peculiarities of the sales figures of pipes by the enterprise. Table 3 shows such data.

Table 3

Pipes sales figures

\begin{tabular}{|l|c|c|}
\hline \multicolumn{1}{|c|}{ Profitability } & $\begin{array}{c}\text { For the reporting } \\
\text { period }\end{array}$ & $\begin{array}{c}\text { For the same period } \\
\text { of the previous year }\end{array}$ \\
\hline $\begin{array}{l}\text { Sales of pipes in local } \\
\text { market }\end{array}$ & 452432 & 500217 \\
\hline $\begin{array}{l}\text { Sales of pipes for } \\
\text { export }\end{array}$ & 1045765 & 1342283 \\
\hline $\begin{array}{l}\text { Total proceeds from } \\
\text { sales of pipes }\end{array}$ & 1498197 & 1842500 \\
\hline
\end{tabular}

Table 3 data analysis shows that the enterprise pays a considerable attention to the sales of pipes for export. The main consumers of the enterprise's products are such countries as the US and China, as well as the EU countries. It should be noted that the enterprise produces pipes for oil and gas sector. And this, in turn, means that the prospects for the expansion of the production of the enterprise directly depend on the oil and gas field development. Against this background, there could be specified several subjective factors that affect the phaseout. The main ones include the following:

- expansion of pipes production by countries that are consumers of pipes' products (USA, China, EU);

- significant aggravation of competitive opportunities in the world markets for pipe products;

- a significant increase in prices for raw materials;

- some activation of the policy of import substitution of Ukrainian pipe products.

It is also possible to point out objective factors that hamper the expansion of the pipe product market. Thus, the price of energy resources has a significant impact on the final cost of pipe products. Abroad pipe plants have the opportunity to buy them at a significantly lower price than local producers do. Clearly, this situation leads to a reduction in the cost of pipe production for abroad enterprises and thus has significant advantages in the competition.

There should also be noted another aspect that has a significant impact on the competitiveness of products. This is the quality. For pipe products, this is primarily due to the increase in the accuracy of the pipes' diameter. This circumstance indicates that today pipe producers are trying to follow American standards. This allows a significant increase in the sales figures of pipes in the US market. On the other hand, this approach opens the prospects of development and other markets, e.g., Central Asian.

The results of the above analysis show that competition in the market of pipe products is quite high. For these reasons, every pipe producer is looking 
for ways to increase the competitiveness of its products. One of the most promising directions for increasing the competitiveness of products for NmTZ OJSC could be the implementation of the energy-saving program. To do this, there was analysed both externals and internals of the enterprise. At the same time, there were spotted the opportunities and the greatest future threats. In this regard, to improve the profitability of the enterprise there were proposed some measures: the investment project involves the improvement of the technology of producing pipes of a certain diameter, which increases the yield of a suitable products and reduce the number of defects, as well as reduce the self-cost and improve the profitability of production. The essence of the design choices is to replace the outdated electrical equipment of one rolling mill with more up-to-date and reliable, namely, the replacement of the relay-contact control system on four motors on serial complete thyristor converters. Modernization of electrical equipment can be carried out at the expense of the depreciation fund.

Direct capital investments were calculated to implement such a proposal. Capital investment in production includes: the costs associated with the purchase of the appropriate equipment, the cost of installation and commissioning, the cost of supporting materials. In general, this project requires 190.35 thousand UAH.

Another strategic direction of the enterprise's energy saving program is the refusal of the open-hearth process and the introduction of the technology of smelting steel processing. Such a transition allows using the local steel. The introduction of such an approach is aimed at reducing the cost of production as the enterprise may partially refuse the purchase of imported production components. Consequently, there is an opportunity to bring the quality of pipe products to the level that meets the regulatory requirements of the European Union, as well as to increase the volume of pipes delivered to the abroad consumers.
In addition, there should be noted that it is advisable for the enterprise to consider a competitive strategy of cost leadership since it may be very relevant to it. Such a strategy aims at reducing costs throughout the chain of the technological process of pipes production. The main purpose of such a strategy is to create a significant advantage over competitors at appropriate costs. For the most part, such a strategy is used by large enterprises with a limited range of products, namely, such as NmTZ OJSC.

The main idea of this strategy is to find opportunities to reduce costs. The use of this strategy could cut production costs by reducing the percentage of defects and by optimizing the production process. With the cost lowering, there supposed the increase in the net profit amount, with the same sales figures, which leads to an increase in profitability indicators.

Therefore, in order to maintain favourable positions in the pipe production market, it is necessary to work systematically in all directions of the enterprise's activity, particularly: improving the quality of products, improving production technologies, and developing new types of products according to the growing market requirements.

\section{Conclusions}

Based on the foregoing, subjective and objective factors hindering the increase of pipe production efficiency are established. The priority directions of the enterprise development are determined. A program of energy saving is proposed to increase the competitiveness of products. In addition, the enterprise was proposed to introduce a competitive strategy of cost leadership. The use of this strategy will cut production costs by reducing the percentage of defects and by optimizing the production process. With the cost lowering, the net profit amount is supposed to increase, keeping the same sales figures, which leads to an increase in profitability indicators.

\section{References:}

Andriichuk, V. H. (2014). Problemni aspekty rehulyuvannya funktsionuvannya ahropromyslovykh kompaniy [Problematic aspects of regulation of the functioning of agro-industrial companies]. Ekonomika APK [Economy of agro-industrial complex], no. 2, pp. 5-21 (In Ukrainian).

Balabanov, I. T. (2007). Finansovyy analiz i planirovaniye khozyaystvuyushchego subyekta [Financial analysis and planning of an economic entity]. Moscow, Finansy i statistika, 206 p. (In Russian).

Blank, I. A. (2007). Upravleniye pribylyu [Profit management]. Kyiv, Nika-Tsentr, 768 p. (In Russian).

Bondar, N. M. (2014). Pro kryteriyi efektyvnosti mekhanizmu derzhavno-pryvatnoho partnerstva [On the criteria of the effectiveness of the mechanism of public-private partnership] Upravlinnya proektamy, systemnyy analiz i lohistyka [Project Management, System Analysis and Logistics], issue 13, p. 244-260 (In Ukrainian).

Hetman, O. O., \& Shapoval, V. M. (2010). Ekonomika pidpryyemstva [Economy of the enterprise]. Kyiv, Tsentr uchbovoyi literatury, 488 p. (In Ukrainian).

Krylov, E. I., \& Vlasova, V. M., \& Zhuravkova, I. V. (2006). Analiz finansovykh rezultatov, rentabelnosti i sebestoimosti produktsii. [Analysis of financial results, profitability and cost of production]. Moscow, Finansy i statistika, 272 p. (In Russian).

Melnyk, L. L. (2013). Naukovi zasady prybutkovosti ahropidpryyemstv ta yiyi derzhavna pidtrymka [Scientific principles of profitability of agro enterprises and its state support]. Investytsiyi: praktyka ta dosvid [Investments: practice and experience], no. 7, pp. 46-49 (In Ukrainian). 
Parshyna, O. A. (2013). Kontseptualni osnovy zabezpechennya konkurentospromozhnosti promyslovykh pidpryyemstv [Conceptual Basis for Providing Competitiveness of Industrial Enterprises]. Teoretychni ta prykladni aspekty pidvyshchennya konkurentospromozhnosti pidpryyemstv [Theoretical and Applied Aspects of Increasing the Competitiveness of Enterprises]. Dnipropetrovsk, Herda, vol. 1, pp. 7-14 (In Ukrainian).

Pokropivnyi, S. F. (2001). Ekonomika pidpryyemstva [Economy of the enterprise]. Kyiv, KNEU, 352 p. (In Ukrainian).

Prokopenko I. F., Hanin V. I. (2008). Metodyka i metodolohiya ekonomichnoho analizu [Methodology and methodology of economic analysis]. Kyiv, Tsentr uchbovoyi literatury, 430 p. (In Ukrainian).

Tumanydze T. U. (2013). Upravlenye proyzvodstvennymy zatratamy predpryyatyya [Management of production costs of the enterprise]. Stratehyya razvytyya ékonomyky [Strategy of economic development], no. 3(202), pp. 24-28 (In Ukrainian).

Sabluk P.T.(2008).Problemyzabezpechennya dokhidnosti ahropromyslovoho vyrobnytstvav Ukrayinivpostindustrialnyy period [Problems of ensuring the profitability of agro-industrial production in Ukraine in the post-industrial period]. Ekonomika APK [Economy of agro-industrial complex], no. 4, pp. 19-37 (In Ukrainian). 